\title{
Pengaruh Merokok Terhadap Perilaku Remaja
}

\author{
Syafrinda Immawan, Muhammad Ali Sodik \\ Institut Ilmu Kesehatan STRADA Indonesia \\ aprinsepron@yahoo.com, alisodik2012@gmail.com
}

\begin{abstract}
Abstrak
Masa remaja merupakan suatu masa dimana seorang individu mengalami transisi dari satu tahap ke tahap berikutnya dan baik perubahan emosi, tubuh, pola tingkah laku, dan juga masalah-masalah remaja yang sangat cenderung memiliki rasa ingin tahu yang besar terhadap merokok. Kebiasaan merokok bagi remaja dimulai karena kurangnya informasi dan kesalahpahaman informasi, iklan atau rayuan dari teman. Banyak orang percaya bahwa merokok bisa menghilangkan stres. Bagaimanapun itu sangat dibenarkan. Hanya efek nikotin yang memberikan rasa tenang sesaat. Jika sudah terlanjur luangkan waktu untuk menghentikan kebiasaan buruk tersebut secepatnya. Mulai dari hidup sehat dan rutin menjaga kesehatan dan memahami bahaya rokok.
\end{abstract}

Kata Kunci: merokok, remaja, nikotin.

\section{Latar Belakang}

Masa remaja merupakan suatu masa dimana seorang individu mengalami transisi dari satu tahap ke tahap berikutnya dan baik perubahan emosi, tubuh, pola tingkah laku, dan juga masalah-masalah remaja yang sangat cenderung memiliki rasa ingin tahu yang besar terhadap merokok. Kebiasaan merokok bagi remaja dimulai karena kurangnya informasi dan kesalahpahaman informasi, iklan atau rayuan dari teman. Banyak orang percaya bahwa merokok bisa menghilangkan stres. Bagaimanapun itu sangat dibenarkan. Hanya efek nikotin yang memberikan rasa tenang sesaat. Jika sudah terlanjur luangkan waktu untuk menghentikan kebiasaan buruk tersebut secepatnya. Mulai dari hidup sehat dan rutin menjaga kesehatan dan memahami bahaya rokok.

Merokok merupakan salah satu masalah yang sulit dipecahkan. Apalagi sudah menjadi masalah nasional, bahkan internasional. Menjadi sulit karena dikaitkan dengan banyak faktor pemicu, sehingga seolah-olah telah menjadi lingkaran setan. Dalam tinjauan dari segi kesehatan, merokok harus dihentikan karena menyebabkan kanker pada penyumbatan pembuluh darah yang 
berakibat kematian, oleh karena itu, merokok harus dihentikan sedini mungkin sebagai upaya pencegahan. Apalagi diketahui bahwa kebanyakan adalah remaja sehingga perlu adanya pencegahan dini yang dimulai dari pihak sekolah dan orang tua.

Perilaku merokok banyak dilakukan pada masa remaja. Pada tahun 2014 menunjukkan bahwa prevalensi remaja usia 16 - 19 tahun yang merokok 20,5 $\%$. Usia merokok pada remaja di Indonesia sekarang adalah usia mulai merokok semakin muda (dini). Perokok pemula usia 10 - 14 tahun meningkat lebih dari $100 \%$ dalam kurun waktu kurang dari 20 tahun.3 Masa remaja adalah masa peralihan dari usia kanak kanak ke usia dewasa. Menurut WHO (World Health Organization) batasan usia remaja adalah $12-24$ tahun.

\section{Konflik/Masalah}

REPUBLIKA.CO.ID, JAKARTA

Kementerian Kesehatan (Kemenkes) mengungkap Indonesia saat ini yang menghadapi ancaman meningkatnya perokok anak dan remaja. Menteri Kesehatan (Menkes) Nila F Moeloek mengatakan kecenderungan peningkatan prevalensi merokok terlihat lebih besar pada kelompok anak-anak dan remaja. "Riset kesehatan dasar (Riskesdas) 2018 menunjukan bahwa terjadi peningkatan prevalensi merokok penduduk usia kurang dari 18 tahun dari 7,2 persen menjadi 9,1 persen," kata Nila pada peringatan Hari Tanpa Tembakau Sedunia (HTTS) 2019 di kantor Kemenkes, Kamis (11/7)

\section{Tinjauan Pustaka}

Rokok adalah hasil olahan dari tembakau kering yang terbungkus sehingga berbentuk seperti cerutu. Sebagian besar rokok mengandung tembakau dan tanaman nicotiana tabacum, nicotiana rustica dan spesies lainnya atau yang mengandung nikotin dan tar dengan atau tanpa bahan tambahan lainnya. Rokok mengakibatkan bahaya bagi kesehatan individu dan masyarakat, karena rokok merupakan salah satu zat adiktif dan perlu dilakukan berbagai upaya pengamanan (H. Kurniasih, et al. 2016). Faktor-faktor yang mempengaruhi perilaku merokok Menurut Juniarti (1991) dalam Mu'tadin (2002) dalam Poltekkes Depkes Jakarta 1 (2012), faktor yang mempengaruhi kebiasaan merokok adalah sebagai berikut:

a. Pengaruh Orang Tua Salah satu temuan remaja perokok adalah bahwa anakanak muda yang berasal dari rumah tangga yang tidak bahagia, dimana orang tua tidak begitu memperhatikan anakanaknya dan memberikan hukuman yang keras. 
b. Pengaruh teman semakin banyak remaja yang merokok maka semakin besar kemungkinan teman-temanya adalah perokok dan demikian sebaliknya. Dari fakta tersebut ada dua kemungkinan yang terjadi. Pertama, remaja tadi terpengaruh oleh teman-temanya, atau bahkan temen-temen remaja tersebut dipengaruhi oleh remaja tersebut.

c. Faktor kepribaian orang coba untuk merokok karena alasan ingin tahu, ingin tahu melepaskan diri dari rasa sakit fisik atau jiwa dan membebaskan diri dari kebosanan.

d. Pengaruh iklan melihat iklan di media massa dan elektronik yang menampilkan gambaran bahwa perokok adalah lambang kejantanan atau glamour. Membuat remaja sering kali terpicu untuk meniru perilaku-perilaku seperti yang ada di dalam iklan tersebut.

\section{Pembahasan}

a. Pengertian Rokok

Rokok adalah salah satu zat adiktif yang bila digunakan mengakibatkan bahaya bagi kesehatan individu dan masyarakat. Kemudian ada juga yang menyebutkan bahwa rokok adalah hasil olahan tembakau terbungkus termasuk cerutu atau bahan lainya yang dihasilkan dari tanamam Nicotiana Tabacum, Nicotiana Rustica dan spesies lainnya atau sintesisnya yang mengandung nikotin dan tar dengan atau tanpa bahan tambahan. (Hans Tendra, 2003).

b. Bahan Baku Rokok

Rokok terbuat dari tembakau yang diperoleh dari tanaman Nicotiana Tabacum L. Tembakau dipergunakan sebagai bahan untuk sigaret, cerutu, tembakau untuk pipa serta pemakaian oral. Di Indonesia, tembakau ditambah cengkih dan bahan-bahan lain dicampur untuk dibuat rokok kretek. Selain kretek, tembakau juga dapat digunakan sebagai rokok linting, rokok putih, cerutu, rokok pipa, dan tembakau tanpa asap (chewing tobacco atau tembako kunyah).

c. Dampak Rokok Bagi Organ Respirasi Merokok dapat menimbulkan berbagai dampak pada kesehatan manusia, baik dampak langsung maupun efek menahun. Dampak ini bisa terkena pada perokok aktif maupun pasif.

1) Dampak langsung merokok:

a) Air mata keluar banyak.

b) Rambut, baju, badan berbau.

c) Denyut nadi dan tekanan darah meningkat.

d) Peristaltik usus meningkat, nafsu makan menurun.

2) Dampak jangka pendek:

a) Sirkulasi darah kurang baik.

b) Suhu ujung-ujung jari (tangan/kaki) menurun.

c) Rasa mengecap dan membau hilang. 
d) Gigi dan jari menjadi coklat atau hitam.

3) Dampak jangka panjang:

a) Kerja otak menurun.

b) Adrenalin meningkat.

c) Tekanan darah dan denyut nadi meningkat.

d) Rongga pembuluh darah menciut.

e) Muncul efek ketagihan dan ketergantungan.

Faktor-faktor penyebab remaja merokok:

1) faktor sosial

faktor terbesar dari kebiasaan merokok dipengaruhi oleh faktor sosial atau lingkungan, dimana karakter seseorang banyak dibentuk oleh lingkungan sekitar, baik keluarga, tetangga, ataupun teman pergaulannya.

2) Kebutuhan menghisap dan mengunyah Setiap orang memiliki kebutuhan untuk mengisap dan mengunyah. Kebutuhan ini mulai ada sejak kita lahir yaitu kebutuhan untuk minum susu, dan secara berangsur-angsur berkurang dan hilang, tetapi pada beberapa orang masih ada sampai dewasa.

3) Respon mengulang otomatis

Ketika seseorang telah melakukan sesuatu berkali-kali dan cukup sering, maka akan tercipta pola pengulangan perilaku tertentu secara otomatis.

4) Faktor Genetik

Tidak semua orang sangat tergantung pada nikotin. Ada beberapa orang yang lebih mudah kecanduan nikotin daripada yang lain, dengan alasan yang masih susah untuk dipahami. Dan alasan-alasan tersebut di yakini di wariskan dalam kode genetik.

5) Kecanduan Pada Sel Saraf

Otak secara normal memiliki substansisubstansi yang memberikan efek penenang dan efek rangsangan pada selsel saraf, dimana substansi-substansi tersebut bekerja dengan cara menempel pada reseptor-reseptor sel-sel saraf. Dan nikotin memiliki efek yang sama dengan substansi-substansi tersebut terhadap saraf, ketika nikotin menempel pada reseptor-reseptor di sel-sel saraf. Dengan menempelnya nikotin pada reseptor, maka otak memproduksi dopamin. Dopamin inilah yang memberikan efek menenangkan dan merangsang organorgan lain, yang memberikan efek menyenangkan dari merokok.

\section{Kesimpulan}

Hampir semua remaja di indonesia membudayakan merokok sebagai aktifitas biasa sedangkan bahaya rokok yang berdampak buruk bagi kesehatan ataupun bagi orang lain, penyakitnya pun tidak biasa hingga menyebabkan kematian. Dorongan untuk berhenti merokok untuk remaja yaitu niat dari diri sendiri dan juga dorongan dari orang lain. Yang bisa di lakukan yaitu mengadakan penyuluhan tentang 
bahayanya merokok. Kalau tidak di hentikan sejak dini akan berdmpak buruk di hari tua nanti.

\section{Daftar Pustaka}

Bahaya Merokok Bagi Kesehatan 29 Des 2013

http://jurnalilmiahtp2013.blogspot.com/2 013/12/bahaya-merokok-bagi-

kesehatan.html 02 Februari 2021 (12.21)

Tinjauan Pustaka Konsep Rokok http://eprints.umm.ac.id/48979/3/BAB\% 20II.pdf 02 Februari 2021 (12.40)

Indonesia Hadapi Ancaman Naiknya Perokok Anak dan Remaja

Kamis 11 Jul 2019 13:49 WIB

Rep: $\operatorname{Rr}$ Laeny Sulistyawati/ Red: Christiyaningsih

https://republika.co.id/berita/gayahidup/info-sehat/19/07/11/pugtm9459indonesia-hadapi-ancaman-naiknyaperokok-anak-dan-remaja 02 Februari 2021

Setyani, A. T., \& Sodik, M. A. (2018). Pengaruh Merokok Bagi Remaja
Terhadap Perilaku dan Pergaulan Seharihari.

Sodik, M. A. (2018). Merokok \& Bahayanya.

Sodik, M. A., Astikasari, N. D., Fazrin, I., Chusnatayaini, A., \& Peristiowati, Y. (2018). Dental health child with retardation mental and parents behavior. Indian Journal of Physiotherapy and Occupational Therapy-An International Journal, 12(4), 278-282.

Sodik, M. A., \& Setyani, A. T. (2018). Effect of Smoking For Teens Against Behavior and Social Interaction.

Siyoto, S., Dwianggimawati, M. S., Sari, D. K., Mufida, R. T., \& Sodik, M. A. (2018). The Effect of Pornography Accessity to Influence Sexual Behavior. Indian Journal of Public Health Research \& Development, 9(12). 